\title{
Social Change and the Culture as the Basic of Wulandoni-Pantai Harapan Reconciliation
}

\author{
Blajan Konradus ${ }^{1^{*}}$, Agustinus Gergorius Raja Dasion ${ }^{2}$ \\ Corresponding Author: ${ }^{*}$ blajankonradus@gmail.com.
}

Article

History:

Submit:

2020-12-15

Publish:

2021-03-05

\section{Abstract}

This study aims to explain social change of post-conflict of the Wulandoni - Pantai Harapan community and what kind of cultural communication space should be built for sustainable reconciliation and peace. The two focus studies above have become very central in reading and analysing the reality of the conflict between the two villages. By using ethnographic method, this study found three things. First, the conflict between Wulandoni and Pantai Harapan villages is not a religious conflict. Even so, it cannot be denied that the discourse on religious conflict was quite developed at that time because the cultural and religious realities of the two villages were quite different. Second, the Wulandoni-Pantai Harapan conflict caused social change and the loss of kinship between the people, especially the loss of the Wulandoni barter market. Third, postconflict reconciliation and peace efforts are immediately carried out thanks to the cultural and economic relations between the people on the south coast of Lembata Island. These social, economic and cultural kinship relationships are important pillars in creating peace and harmony between communities. This study also opens the discourse of reconciliation and peace based on local culture and economy in the south of Lembata Island. Keywords: Conflict, Reconciliation, Peace, Culture, Economy

Journal Homepage http://ijssr.net/index.php/ijssr

This is an Open Access article under the CC BY SA license

https://creativecommons.org/licenses/by-sa/4.0/

Published by Indonesian Academy of Social and Religious Research 


\section{Introduction}

Conflict over boundaries is not a new phenomenon in the life of Indonesian society. Conflict occurs when there are different perceptions about something (Pritchard, 2002) These conflicts usually occur because of overlapping land uses for certain community needs. As for territorial boundary conflicts between villages, they are often discussed as conflicts between interests, groups and races, and even religion. Even politically, territorial boundary conflicts are often discussed as merely administrative boundaries without explaining the rights and justice of local communities (Kolers, 2009). The discourse of identity conflict is even at a certain point stronger and more blocked than the reality of the conflict or dispute over the territory or border itself.

The territorial boundary conflict that developed into a discourse on religious conflict in the village of Wulandoni, Lembata Regency, six years ago became a bitter story for the development of religious tolerance in NTT. The conflict involved two villages, namely Wulandoni village which is majority Catholic and Pantai Harapan village which is majority Muslim. The conflict occurred because the two villages claimed rights to the area or land around the Wulandoni coast. The conflict that claimed the lives of these can be resolved by law and custom. However, of the two conflict resolutions, culture-based reconciliation is the most important and foremost.

\section{Literature Review}

Bahari's research (Bahari, 2008) in North Kalimantan describes the reconciliation of the Malay vs Madura conflict using a cultural communication model. The Bahari study describes a cross-cultural communication model in conflict resolution in West Kalimantan. In addition, Ode's study (Ode, 2016)a new sampling method called headspace mulberry paper bag micro solid phase extraction (HS-MPB-1-SPE describes a model of conflict resolution through local wisdom in Maluku. Conflicts between Christianity and Islam can be resolved with the pela tradition. The Pela Cultural Tradition is a hereditary consensus that aims to unite people between countries. Apart from being a historical consensus, the pela cultural tradition also functions as a medium for resolution and resolution media in case of conflicts or disputes in society, both on a small to large scale. Nufta \& Anwar (Nutfa \& Anwar, 2015) explain efforts to rebuild post-conflict

1 https://www.mediantt.com/2015/02/24/wulandoni-dan-luki-berdamai-pasar-barter-dibukakembali/ 
community peace through strengthening social capital starting from building the main social capital, namely trust between communities.

The studies above have opened up a discourse on how important culture is in building conflict reconciliation. However, the focus of several studies above is more on efforts to build a reconciliation of identity and race conflicts. This study focuses more on conflict in border areas and efforts to build reconciliation based on the culture and local wisdom of the southern coastal communities of Lembata.

The urgency of this research is to re-open spaces of cultural, economic and customary discourse that can unite the people of Wulandoni and Pantai Harapan villages. The main thesis of this paper is that the reconciliation of the WulandoniPantai Harapan conflict must begin by strengthening the social, economic and cultural systems that are the pillars of life together. The intensity of meetings and kinship in the social, economic and cultural system between communities on the south coast of Lembata Island is a strong pillar in maintaining community harmony and even becomes a kind of "magic" to restore harmony in the event of conflict.

\section{Methods}

This research method uses an ethnographic approach. Ethnographic studies are holistic, integrative, thick description, and qualitative analysis to get a "native point of view" (Wilson \& Chaddha, 2009). Choosing an ethnographic approach considers two basic things. First, the researcher wants to see how cultural unity (including various local values) becomes the basis for the reconciliation of the Wulandoni and Pantai Harapan communities. Second, ethnography is an approach that allows all customary systems and socio-cultural systems to be seen more thoroughly. This is very important because conflicts that occur at the local community level can only be resolved according to local customs and culture. Local stakeholders are the key figures in a conflict that can be resolved immediately.

\section{Findings}

\subsection{Wulandoni-Pantai Harapan Peace Agreement}

After the conflict, each party tried to rebuild life together peacefully. Researchers found that after the conflict, the two warring parties did not want to prolong the problem by finding who was right and who was wrong. This 
is evidenced by the efforts of various stakeholders from both villages and the government in finding opportunities to immediately carry out reconciliation and a peace agreement.

There are two peace agreements after the conflict in the village of Wulandoni and Pantai Harapanaan. First, legally formally, the peace agreement is contained in the Peace Deed Number 08 / PDT.G / 2014 / PN Lembata which contains four points ${ }^{2}$.

1. The two warring parties agree to forgive each other and end the lawsuit in a peaceful manner.

2. agree to be harmonious and return to fostering a sense of kinship and guarantee a sense of security and comfort for the residents of the two villages as inherited from their predecessors.

3. Both parties agree that the contested area conditions remain based on the beliefs of each party, and the building that was built on August 16, 2014 and which triggered the dispute is considered non-existent.

4. Both parties agreed to reopen the Wulandoni barter market, which had been suspended due to clashes between the villages.

In addition, the community and stake holders (traditional elders and community leaders) from both villages, as well as neighbouring villages, took the initiative to carry out peace rituals or ceremonies. They believe that any conflict can only be resolved by traditional ceremonies. They believe that the owner of land and sea (Lera Wulan Tanah Ekan), as well as their ancestors who have preceded them, will be angry if the conflict continues and does not end with a peaceful effort. The Lamaholot culture always teaches us to be reconciled if there is a conflict or dispute.

The willingness to make peace according to custom was finally carried out on Saturday, August 5, 2017 at the football field, in front of the Wulandoni subdistrict office. This ritual of reconciliation and peace is called sare dame. The sare dame ritual ends with the reading and signing of the peace memorandum. The "sare dame" document was signed by all customary and state stakeholders.

After the two reconciliation efforts written above were carried out, the two conflicting parties tried to return to a good life and did not repeat the conflicts that had occurred. The two peace documents are now stored at the village office and used as a legal basis for safeguarding community life in the future. The peace

2 https://nasional.tempo.co/read/1398961/ 
agreement has been socialized to the people of the two villages, so that the community has begun to understand the risks that will be borne if they return to doing things that can lead to conflict.

\subsection{Social Change of Wulandoni-Pantai Harapan Post-Conflict \\ 4.2.1. Alienation" from Living Together}

The conflict that occurred between the villagers of Wulandoni and Pantai Harapan resulted in a loss of the "sense" of togetherness that had been built so far. Although now the atmosphere has gradually recovered, the close relationship that has been carried out so far has not returned to its original state. GB, a resident of Wulandoni village, explained that the conflict changed all togetherness in life. Usually a familiar atmosphere is always present in the daily life of the people of Wulandoni and Harapan Beach. When they passed, they always greeted each other and even visited each other just to ask each other's news. This close relationship is always built together, especially in bartering transactions and subsistence economies, as well as in various religious holidays. During Christmas, the people of Panatai Harapan Village always take part in maintaining security and order of the Wulandoni Catholics' Christmas celebrations. Likewise, on the other hand, when the Pantai Harapan Muslim community celebrated, the Wulandoni community also took part in the celebration. The relationship between the people of Wulandoni and Pantai Harapan has been well developed and cannot be separated from one another.

However, the conflict changed all kinship relations. For GB, even some people's actions cannot be resolved. Now, over time, people have started to try again to build life together again as before. Besides, after the conflict, many people tried not to return to discussing the bloody tragedy. For some people, discussing the tragedy will only generate a sense of trauma and resentment. This argument is not without reason. Many people think that by forgetting the tragedy, the conflicts that have occurred will not be repeated. However, at another point, the urgency to return to "telling" about the tragedy becomes an opening way to build a life together without repeating the same mistakes or experiences.

$\mathrm{RG}$, as a community leader, when contacted, clearly replied that it was better not to recount the tragedy because for him the conflict had been declared complete and could not be extended again. RG felt that keeping his mouth shut so as not to return to tell about the tragedy was considered the best way to maintain togetherness between the people who were now starting to wake up. 
Researchers have actually tried to explain that this research is not to reopen the "wounds" of society about the tragedy that occurred several years ago. However, RG still replied that the "wounds" caused by the conflict had not fully healed. For this reason, they are not allowed to return to ask questions about the conflict. $\mathrm{RG}$ even asked researchers to look for other topics if they wanted to continue to research and talk about Wulandoni and Pantai Harapan. In this case, at a certain point, researchers find it difficult to obtain more complete data about the conflicts that have occurred and efforts to maintain peace continuously for the common good. However, this refusal did not make researchers stop their efforts to explore how the life of the post-conflict community and how the efforts to rebuild a life together that had been broken up and "disturbed".

\subsubsection{The Fading of Kinship "Prefo"}

It must be admitted that the Wulandoni barter market does not merely explain a local economic transaction. The Wulandoni barter market is even more than just a sale and purchase transaction or exchange of goods because it describes a new kinship called prefo. Prefo is a new kinship relationship outside of family relations which was formed due to barter transactions between coastal communities and mountainous communities in the southern region of Lembata Island (Blikololong, 2010; Dasion, 2019; Dasion \& Nugroho, 2020),.

The sale and purchase transaction $(d u-h o p e)$ at the Wulandoni barter market always comes in a consensus through very "intimate" communication. The researcher uses the word "intimate" to explain that the process of interaction and communication in the practice of buying and selling $(d u-h o p e)$ is full of a high sense of kinship, trust, and altruism. Thus, in every trading practice, a kinship is created which is called prefo. Prefo can be defined as kinship, outside of the biological relationship, which is created by the buyer and seller during the salebuy interaction $(d u-h o p e)$.

Prefo itself usually comes with the following conditions. First, prefo usually occurs when one of the parties (either the seller or the buyer) does not have the same value as the item to be exchanged. For example, the prefo relationship occurs when fish are readily available but mountain produce such as maize or rice is not of sufficient value to exchange for existing fish. Thus there was an agreement to continue to do sale and purchase transactions (du-hope), but the buyer ( $k f e l e$ ) would still provide the remaining agricultural products in the next sale and purchase transaction. The opposite can also happen, namely when the 
value of agricultural products such as corn and rice is available, but the value of the fish carried does not match the goods owned by the buyers (kfele). In addition, the prefo relationship can also occur when one party (seller or buyer) can borrow anything, such as fish from the seller (pnete alep) or agricultural products from the buyer ( $k f e l e)$, without any items to be exchanged. Transactions like this are the same as debt or borrowing transactions with kinship consensus without a written agreement.

This prefo relationship gives rise to what is called social trust between coastal communities (Lamalera and Wulandoni) and communities in mountain villages (such as Lewuka, Puor, and Posiwatu). Prefo is built on mutual trust with the aim of helping each other between the seller (pnete alep) and the buyer (kfele). There are two important theses of the relationship with which formed in prefo. First, Prefo is total, non-exchangeable trust. The prefo relationship never considers borrowed charcoal as an effort to enrich themselves. Borrowed items are an expression of the highest trust from a person in another. Second, prefo is the spirit of solidarity with coastal communities and people in the mountains. Prefo comes from the belief of coastal communities that marine products such as whales or other fish must also be felt by mountain communities. This is what causes social responsibility and a sense of social solidarity between communities in coastal and mountainous areas to be closely intertwined.

The conflict caused kinship relations (prefo) to seem tenuous, even breaking up. The loss of trust between communities makes it difficult to re-establish prefo relationships. Conflicting societies no longer provide space for communication and economic interaction. They chose to build new "prefo" relationships with people from villages or villages who were still the same ethnicity and religion. This can be seen when at the beginning of the conflict, the prefo relationship pattern changes. The Wulandoni people, who previously had prefo relationships with the Pantai Harapan and Labala communities, are trying to build new relationships with people from the mountains such as Lewuka, Puor, and Posiwatu.

\subsubsection{Loss of "Authenticity" of Wulandoni Barter Market}

The conflict that occurred caused a very crucial change to the economic system of the local community around the village of Wulandoni. The life of the coastal and mountainous communities around the village of Wulandoni always depends on the presence of the Wulandoni barter market which is more than a century old. Coastal communities such as Wulandoni, Lamalera, Pantai Harapan, 
Lebala and mountainous communities such as Lewuka and Puor rely heavily on the Wulandoni barter market. The barter market that maintains the tradition of bartering goods is the most typical thing in market practice in Wulandoni.

The conflict caused severe paralysis of the local community's economy. After the conflict, the Wulandoni barter market was closed for almost a year. Coastal communities (such as the people of Lamalera, Wulandoni, Labala) and mountain communities (such as Lewuka, Puor, Posiwatu) find it difficult to get foodstuffs to sustain their lives. Coastal communities really need products from their gardens such as rice, sweet potatoes, corn and vegetables from the pegunugan community. Likewise, with mountain communities, they need marine products such as fish and snails to meet their food needs. This situation became very difficult. AT, one of the fishermen of Lamalera, explained that the people of Lamalera really depend on the Wulandini barter market because the barter market is a very historic "local" market for the people of Lamalera and Wulandoni.

The Wulandoni barter market is a very important historical market during the exodus period of the Lamalera people. Before arriving in Lamalera, the people of Lamalera stopped and settled in Wulandoni, which at that time was known as Doni Nusa Lela (Lundberg, 2003). The people of Lamalera sell their catch with plantations from the Lewuka people who at that time were farming in the area around the Wulandoni coast.

\subsubsection{The emergence of the Lamalera Barter Market}

The conflict and the absence of a Wulandoni barter market have caused people who already have ties or a local economic exchange system to seek new, more "neutral" places to conduct bartering transactions. The coastal communities and the mountain communities who have developed an economic system together for a long time finally determined Lamalera to be the place for the barter market to be conducted. Several stakeholders of the villages (villages) who took part in the traditional practice of the Wulandoni barter market finally agreed to continue to practice the barter market in Lamalera.

The presence of the Wulandoni market, scientifically can be explained as the existence of interdependence, the existence of reciprocity between mountain communities and coastal communities. The market is used as an arena for a sense of togetherness, kinship, and mutual assistance between coastal communities and mountain communities, which due to differences in geographical conditions cause dependence on other needs (Hamado et al., 2015). Blikololong (2010) 
explains that bartering in Wulandoni, the Solor islands, even Alor and Pantar occurs between coastal and inland residents for subsistence purposes, mostly in the form of exchanging marine and garden products. With different geographical conditions, coastal and inland areas do not produce competitive goods but are complementary.

The decision to establish a barter market in Lamalera was greeted enthusiastically by the people of Lamalera and the surrounding villages. There are two things that must be explained regarding the establishment of the "new" barter market in Lamalera. First, the holding of the Lamalera barter market certainly had a significant local economic effect. For nearly a year people live in fear and confusion because they don't get food like they do every week. The Lamalera barter market has since opened, drawing the attention of many local traders who want to exchange their goods for other goods they need. The presence of the Lamalera barter market also explains that the kinship relationship that was once strained can actually be restored immediately with familial transactions in the practice of buying and selling $(d u-h o p e)$. Second, although the presence of the Lamalera barter market provided fresh air for local residents in the southern part of the island of Lembata, the presence of the Lamalera barter market initially "excluded" the people of Pantai Harapan and Lebala. The two villages whose people embraced Islam religion felt "isolated" and did not take part in the Lamalera barter market transactions. This fear is not without reason, as a minority in the southern part of Lembata, they certainly still feel afraid to carry out barter transactions with neighboring villagers who had opposition to the conflict that had occurred. This situation even lasted for almost a year. But with a determination to build a better living system, in the end fear and anxiety change. Now the people of Panatai Harapan village have again taken part in the sale and purchase transaction ( $d u$ hope) at the Lamalera barter market.

\section{Discussion}

This study will not be complete if it does not explain how the opportunities to build a life together after the conflict and how to maintain kinship patterns that will be a powerful weapon for every conflict that occurs. This section is certainly not a solution or a way out of how to maintain life together in order to avoid various kinds of conflicts that can arise at any time. This section is a contribution to the analysis of studies that have been carried out. The researcher argues that there are two things that should be discussed so that the conflict 
which becomes a "dark history" of the life of the people on the south coast of the island of Lembata will not be repeated.

\subsection{State and Certainty of Territorial Boundaries}

Many conflicts occur in Indonesia because the state turns a blind eye to various small ripples of conflict over territorial boundaries. The conflict over the boundaries of the villages of Wulandoni and Pantai Harapan is one proof of how the state is not too serious about ensuring and resolving various territorial boundary issues between one village and another.

The Deputy Regent of Lembata at that time, VM, when interviewed by one of the national media, explained that the division of Lembata District from East Flores Regency affected the regional expansion at the village and sub-district levels. One of the expansion areas, namely Atadei District and Nagawutung District, was further expanded into Wulandoni District. The expansion has implications for the expansion of the village so that Lamalera Village is expanded with Wulandoni Village, the same as Leworaja Village which is expanded again with Pantai Harapan Village. However, it was explained that the division of the village area was only an administrative document. In practice, there is no socialization and laying of boundaries or pillars between regions in the field. ${ }^{\bigotimes}$

With this tragedy, the steps that must be taken immediately are to form a task force or work unit that specifically resolves various problems related to administrative boundaries. This is the most rational first step because it can prevent various conflicts that might erupt if not handled properly.

\subsection{Customs and Culture}

This study found that there are urgent things that must be done apart from resolving conflict problems administratively and formal legal law. What must be done is how to restore a "sense of peace" in the life together between the people of Wulandoni and Pantai Harapan. Researchers have found that strengthening the local economic system is one of the most effective and most potent bonds of life together.

The reality shows that the economic life of coastal and mountainous communities in the southern region of the island of Lembata always depends on or depends on the presence of the Wulandoni barter market. This is also the case with the Wulandoni community and the Panti Harapan community. 
The economy of the two villages is highly dependent on the presence of the Wulandoni barter market. Thus, it is strange if efforts to strengthen friendship and post-conflict reconciliation are neglecting the local economic system of life. It must be admitted that the absence of a market in Wulandoni, which has occurred for almost a year, has greatly "disturbed" the lives of the two villages and the surrounding villages. Thus, maintaining the Wulandoni barter market, including various local wisdoms in it, such as kinship (prefo) is an urgent matter.

The presence of the market creates the intensity of the people to meet each other to greet each other and give mutual attention to one another. The villagers on the coast will feel that the village community in the mountains are "their other selves" so that the presence of other communities is a necessity for their survival, and vice versa. The absence of their "other selves" (other village communities) is a threat to the survival of a particular community identity.

The basis for mutual need and giving to one another in the practice of barter market transactions fosters mutual guardianship and does not quickly lead to conflict. Not only that, providing the widest possible space to re-open the barter market in Wulandoni is an urgency because the barter market itself is a spirit of "togetherness" between coastal communities and mountain communities, south of Lembata Island.

In addition to maintaining the "spirit" of togetherness in the Wulandoni barter market, efforts to build a post-conflict life together can also be done by strengthening ties between cultural and religious adherents to one another. It must be emphasized that the Wulandoni-Pantai Harapan conflict is not a religious conflict. However, the reality of cultural and religious differences between communities must be taken into account, as well as used as a tie. Researchers, when conducting previous research on "prefo" and social relations between the coastal communities of Lembata Island, found that the people of Wulandoni and Pantai Harapan helped each other and participated in various cultural or religious activities respectively. Until now, after the conflict, the attitude of mutual assistance and attention, by taking part in various cultural and religious activities should be nurtured again.

The practice of helping each other in all cultural and religious activities seems to be a "blessing" that must be maintained because it becomes one of the binders for the harmony of life in the Lembata community. With this study, it is hoped that the stake holders can reopen the space for dialogue and build an effort to live together by helping each other and "care" one another. The practice 
of living with mutual concern between one community and another has proven to be an effort to prevent conflicts and divisions between people of different cultures, ethnicities and religions.

\section{Conclusion}

Conflict always leaves wounds and victims. What matters most in a conflict is not trying to explain which side is wrong and which side is right. The substance of breaking down conflict issues is actually focused on trying to see how each of these relationships can lead to conflict, as well as opening up opportunities for how these relationships can be repaired. Only the will to unite and live together can open space for peace (Bloomfield et al., 2003), and this is the substance of reconciliation.

The conflict between the people of Wulandoni and Pantai Harapan should not only be read in terms of efforts to defend their territory and identity. The conflict must be parsed and read in the framework of the presence of a "common will" to return to fostering a better and peaceful life after the conflict. The reality of peaceful efforts that have now produced results is proof of how the two parties have a basis for a good and peaceful life together.

This study ultimately proves that the Wulandoni and Pantai Harapan conflicts can be resolved properly because each party has the will to immediately make peace. The socio-cultural background, and especially the economy, "requires" both parties to maintain togetherness. Damaging relations between the two parties is the same as risking the economic system of each village. This study proves once again that cultural and economic realities can bind life together with coastal and mountainous communities, in the southern part of the island of Lembata.

\section{References:}

Alvar, Michael. Genetic and Cultural Kinship among the Lamaleran Whale Hunters. Springer Science Business Media. Vol. 12, no.22 (2001)

Alvar, Michael. Kinship, Lineage, and An Evolutionary Perspective on Cooperative Hunting Grups In Indonesia. Human Nature. Vol. 14, no. 2 (2003).

Bahari, Y. Intercultural Communication Model in Conflict Resolution Based on Malay and Madurese Customary Institutions in West Kalimantan. 2008. Jurnal Ilmu Komunikasi UPNYK, 6(1), 103867. 
Blikololong, J. B. Dissertastion. Du-hope di Tengah Penetrasi Ekonomi Uang. 2010. Bloomfield, D., Barnes, T., \& Huyse, L. Reconciliation after Violent Conflict. A Handbook. In Differences. 2003. http://www.idea.int/publications/ reconciliation/upload/reconciliation_full.pdf

Dasion, A. G. R.. Seizing Whales in the Savu Sea: Conflict of Interest for Whale Conservation between the State and the People of Lamalera, East Nusa Tenggara. 2019. Jurnal Pemikiran Sosiologi, 6(1), 41. https://doi. org/10.22146/jps.v6i1.47466

Dasion Agustinus, \& Nugroho, H.. "Badu” Tradition as Local Conservation and Food Sharing System for the Poor. 2020. Komunitas: International Journal of Indonesian Society and Culture, 12(2), 118-126.https://doi.org/10.15294/ komunitas.v12i1.22825

Hamado, A., Umar, R., \& Maru, R. The Existence of the Barter Market in the Middle of the Rapid Development of Modern Markets: The Case of the Barter Market in Wulandoni District, NTT, from an Economic Geographical Perspective. Universitas Negri Makasar. 2015

Kolers, A. Land, Conflict, adn Justice. Cambridge University Press. 2009.

Ode, S. Local Culture as Media of Conflict Resolution and Control in Maluku Province (Study, Challenges and Revitalization of Pela Culture). POLITIKA : Jurnal Ilmu Politik, 6(2), (2016), https://doi.org/10.14710/ politika.6.2.2015.93-100

Robert D. Pritchard, E. The Psychology of Conflict and Conflict Management in Organizations. ta. 2002.

Scot, James. Moral Economy of The Peasant. USA: Yale University Press. 1987

Taylor, Eduard B. Primitive Culture: Researches into the Development of Mythology. 1971.

Philosophy, Religion, Language, Art and Custom. London: J. Murray. Thomas, J. Doing Critical Ethnography. 1993.

Wilson, W. J., \& Chaddha, A. The role of theory in ethnographic research. 2009. Ethnography, 10(4), 549-564. https://doi.org/10.1177/1466138109347009 
